\title{
PENERAPAN MODEL PEMBELAJARAN COOPERATIVE SCRIPT UNTUK MENINGKATKAN PRESTASI BELAJAR PESERTA DIDIK PADA MATERI KESETIMBANGAN ION DAN PH LARUTAN PENYANGGA
}

\author{
Yolanda Ariska*, Johni Azmi, Betty Holiwarni
}

Program Studi Pendidikan Kimia, Fakultas Keguruan dan Ilmu Pendidikan Universitas Riau, Indonesia

\begin{tabular}{l}
\hline \multicolumn{1}{c}{ Informasi Artikel } \\
\hline Sejarah Artikel: \\
Diterima: 16-07-2019 \\
Disetujui : 21-07-2020 \\
Dipublikasikan: 24-07-2020 \\
\hline Keywords: \\
Cooperative script, \\
Learning achievement, \\
Equilibrium ion, \\
pH buffer aolution \\
\hline
\end{tabular}

\begin{abstract}
A b s t r a k
Tujuan dari penelitian ini adalah untuk meningkatkan prestasi belajar peserta didik dengan menerapkan model pembelajaran cooperative script pada materi kesetimbangan ion dan $\mathrm{pH}$ larutan penyangga pada kelas XI MIA SMA Negeri 9 Pekanbaru. Penelitian yang dilakukan ini merupakan penelitian berjenis eksperimen dengan menggunakan pretest-postest. Pelaksanaan penelitian ini di SMA Negeri 9 Pekanbaru dengan sampel penelitian ini adalah siswa kelas XI MIA 2 yang merupakan kelas eksperimen dan siswa kelas XI MIA 3 merupakan kelas kontrol. Dimana kelas eksperimen merupakan kelas yang diterapkan model pembelajaran cooperative script, sedangkan kelas kontrol tidak menerapkan model pembelajaran tersebut. Pada penelitian ini data digunakan dengan teknik analisis data uji-t. Dari hasil uji analisis data didapatkan thitung $>$ tabel yaitu $3,74>1,66$, dengan arti penerapan model pembelajaran cooperative script dapat meningkatkan prestasi belajar peserta didik pada pokok bahasan kesetimbangan ion dan $\mathrm{pH}$ larutan penyangga di kelas XI MIA SMA Negeri 9 Pekanbaru.
\end{abstract}

\begin{abstract}
A b s tract
The purpose of this study was to improve student learning achievement in ion and pH equilibrium material and applied on class XI MIA SMA Negeri 9 Pekanbaru. This research is an experimental research using pretest-posttest. The implementation of this research in Pekanbaru 9 High School with the sample of this study was the XI MIA 2 students who were the experimental class and the XI MIA 3 students were the control class. Where the experimental class is a class that is applied cooperative learning models, while the control class does not apply the learning model. In this study the data used by the t-test data analysis technique. From the data analysis test results obtained t count > t table is 3.74> 1.66, with the meaning that the application of cooperative learning models can improve student achievement on the subject of ion balance and pH of buffer solution in class XI MIA SMA Negeri 9 Pekanbaru.
\end{abstract}

(C) 2020 JPK UNRI. All rights reserved

*Alamat korespondensi:

e-mail: yolandaariska1611@gmail.com

No. Telf: +6281365554115 


\section{PENDAHULUAN}

Kimia adalah cabang Ilmu Pengetahuan Alam (IPA) yang dipelajari di Sekolah Menengah Atas (SMA) mempelajari tentang materi, struktur, susunan, sifat dan perubahan materi serta energi yang menyertainya (Nugraha dan Nugraha 2008). Pembelajaran kimia memiliki potensi yang besar dan peranan strategis dalam menyiapkan sumber daya manusia yang berkualitas untuk menghadapi era industrial dan globalisasi. Potensi ini dapat terwujud dari proses pembelajaran yang diperoleh peserta didik di sekolah. Oleh sebab itu, proses pembelajaran di sekolah menjadi sorotan penting untuk meningkatkan sumber daya manusia yang berkualitas. Indikator keberhasilan proses pembelajaran kimia salah satunya adalah peserta didik memiliki kemampuan untuk menyelesaikan permasalahan yang dihadapinya, baik dalam bentuk soal maupun permasalahan yang berasal dari kehidupan seharihari. Untuk meningkatkan kemampuan peserta didik tersebut perlu adanya pembelajaran aktif dalam setiap kegiatan di sekolah terutama pada pembelajaran kimia.

Model pembelajaran dapat digunakan sebagai salah satu peranan untuk membuat kegiatan pembelajaran menjadi aktif sehingga dapat berpengaruh pada prestasi belajar murid. Model pembelajaran dapat diartikan sebagai suatu perencanaan atau suatu pola yang digunakan sebagai pedoman dalam melaksanakan pembelajaran di kelas (Yamin, 2013). Penetapan model pembelajaran disesuaikan dengan materi pelajaran agar peserta didik tertarik dan termotivasi dengan materi pelajaran sehingga dapat memberi efek pada peningkatan prestasi belajar peserta didik, termasuk dalam pembelajaran kimia.

Keterangan yang diperoleh dari hasil tanya jawab dengan guru kimia kelas XI MIA SMAN 9 Pekanbaru bahwa tingkat hasil ulangan harian yang diperoleh peserta didik pada subjek kesetimbangan ion dan pH larutan penyangga pada tahun 2017/2018 masih pada tingkat rendah. Rendahnya tingkat hasil ulangan perserta didik dengan persentase $56 \%$ yang belum mencapai Kriteria Ketuntasan Minimal (KKM) yang telah ditetapkan sekolah yaitu 80. Belum tercapainya tingkat KKM ini dikarenakan peserta didik yang kurang aktif dalam kegiatan pembelajaran. Dimana para peserta didik kebanyakan hanya menunggu sajian materi yang diberikan oleh guru dan tidak berusaha sendiri untuk menemukan konsep dari materi yang akan dipelajari. Untuk mengatasi hal itu guru telah berusaha menerapkan metode seperti diskusi kelompok, tetapi dalam penerapannya hanya 1-2 orang peserta didik saja yang ingin terlibat dalam diskusi. Kegiatan pembelajaran biasanya mendominasi peserta didik yang berkemampuan tinggi, sehingga peserta didik dengan kemampuan menengah kebawah tidak berperan banyak dalam diskusi dimana hanya menunggu jawaban dari temannya. Dalam penyampaian hasil diskusi, hanya peserta didik yang aktif dalam diskusi kelompok yang dapat memahami materi, sedangkan peserta didik yang kurang aktif dalam diskusi tidak bisa menjawab pertanyaan yang diberikan dari teman-temannya tentang materi diskusinya. Lemahnya keaktifan peserta didik dalam pembelajaran menjadikan peserta didik tidak termotivasi dalam mengikuti proses belajar, maka berdampak dengan prestasi belajar peserta didik yang semakin rendah. Berdasarkan keterangan keadaan tersebut maka diperlukannya model pembelajaran yang bisa mendorong peserta didik untuk aktif dan lebih memotivasi dalam mengembangkan pengetahuannya sendiri sehingga berdampak pada peningkatan prestasi belajar dengan menerapkan model pembelajaran Cooperative Script.

Model pembelajaran Cooperative Script merupakan model pembelajaran yang mengembangkan upaya kerja sama dalam mencapai tujuan bersama, dapat meningkatkan pemahaman peserta didik, dan dapat meningkatkan hasil belajar peserta didik (Jacobs, et al., 1996). Model pembelajaran Cooperative Script menuntut peserta didik untuk memahami konsep awal terlebih dahulu dengan sendirinya, kemudian para peserta didik mendiskusikan secara aktif dengan kelompoknya dengan bimbingan dari guru dan peserta didik dituntut untuk terlibat aktif dalam proses 
pembelajaran agar peserta didik dapat memahami materi yang lebih baik (Kristaliningtyas, et al., 2018).

Menurut Aris (2014) model pembelajaran cooperative Script memiliki keunggulan yaitu dapat melatih pendengaran, ketelitian dan kecermatan peseta didik, setiap peserta didik mendapatkan kesempatan untuk mengungkapkan ide atau pendapatnya, melatih peserta didik mengevaluasi hasil diskusi untuk diselesaikan bersama. Melalui model pembelajaran cooperative Script, peserta didik dengan lancar berinteraksi sosial, sehingga mengembangkan keterampilan berdiskusi, dan peserta didik bisa lebih menghargai orang lain. Peneliti yang lain juga (Norshofiati et al 2017) melakukan penerapan pembelajaran cooperative script yang dikombinasikan dengan model think pair share untuk meningkatkan kemampuan berfikir kritis siswa. Hasil penelitian ditemukan terdapat perbedaan secara signifikan berpikir kritas antara model cooperative script dengan mode think pair share. Penelitian ini bertujuan untuk menerapkan model pembelajaran cooperative script untuk meningkatkan prestasi belajar peserta didik. Penelitian ini dijalakan pada kelas XI MIA SMA Negeri 9 Pekanbaru pada materi kesetimbangan ion dan $\mathrm{pH}$ larutan penyangga.

\section{METODOLOGI PENELITIAN}

Pelaksanaan penelitian dilakukan di SMA Negeri 9 Pekanbaru pada semester genap tahun ajaran 2018/29019. Data diambil dalam kurun waktu dari bulan Maret hingga April 2019. Penelitian ini terdiri dari populasi seluruh peserta didik kelas XI MIA di SMA Negeri 9 Pekanbaru yang terdiri dari 4 kelas yaitu XI MIA 1, XI MIA 2, XI MIA 3, XI MIA 4. Pengambilan sampel dari hasil analisis uji normalitas dan homogenitas nilai ulangan kesetimbangan ion dan $\mathrm{pH}$ larutan garam. Hasil dari uji normalitas dan uji homogenitas didapatkan kelas XI MIA 2 dan XI MIA 3 berdistribusi normal dan mempunyai kemampuan yang sama (homogen), kemudian kedua kelas tersebut dijadikan sebagai sampel. Diambil kelas XI MIA 2 sebagai kelas eksperimen dan kelas XI MIA 3 sebagai kelas kontrol. Penelitian ini merupakan penelitian eksperimen yang dilakukan terhadap dua kelas dengan Desain Randomized Control Group Pretest-Posttest seperti Tabel 1.

Tabel 1. Rancangan Penelitian

\begin{tabular}{lccc}
\hline Kelas & Pretest & Perlakuan & Posttest \\
\hline Eksperimen & $\mathrm{T}_{0}$ & $\mathrm{X}$ & $\mathrm{T}_{1}$ \\
Kontrol & $\mathrm{T}_{0}$ & -- & $\mathrm{T}_{1}$ \\
\hline
\end{tabular}

Data dalam penelitian ini dikumpulkan dengan menggunakan teknik test prestasi belajar. Pengumpulan data tersebut diperoleh dari : (1) Data hasil nilai test ulangan kesetimbangan ion dan $\mathrm{pH}$ larutan garam sebagai data awal yang digunakan untuk uji homogenitas. (2) Nilai pretest dan posttest pada kelas eksperimen dan kelas kontrol (pokok bahasan kesetimbangan ion dan $\mathrm{pH}$ larutan penyangga) digunakan untuk uji hipotesis. Sedangkan untuk menganalisis data menggunakan uji-t. Pengujian statistik dengan uji-t akan dilakukan berdasarkan kategori data yang berdistribusi normal. Maka dari itu, sebelum dilakukan pengolahan data, terlebih dahulu melakukan uji normalitas menggunakan uji Liliefors. Jika harga Lmaks $<$ Ltabel, maka data berdistribusi normal, dimana harga Ltabel diperoleh dengan Persamaan 1 (Rostina, 2014).

$$
L=\frac{0,886}{\sqrt{n}}
$$

Ketika data sudah berdistribusi normal, selanjutnya akan menguji varians kedua sampel dengan menggunakan uji homogenitas dengan Persamaan 2: 


$$
\mathrm{F}=\frac{\text { Varians Terbesar }}{\text { Varians Terkecil }}
$$

Selanjutnya menggunakan uji-t dua pihak sebagai uji kesamaan rata-rata untuk mengetahui kehomogenan kemampuan kedua sampel. Uji-t pada uji homogenitas juga digunakan untuk melihat perubahan hasil belajar seperti prestasi belajar peserta didik antara kelas eksperimen dan kelas kontrol. Uji hipotesis yang digunakan adalah uji-t pihak kanan dengan rumusan Persamaan 3 dan nilai $\mathrm{Sg}$ ditentukan dengan persamaan 4 (Sudjana, 2005).

$$
\begin{array}{|c|}
\mathrm{t} \frac{\overline{x_{1}}-\overline{x_{2}}}{g \sqrt{\frac{1}{n_{1}}+\frac{1}{n_{2}}}} \\
\mathrm{Sg}_{2}=\frac{(n 1-1) S 1^{2}+(n 2-1) S 2^{2}}{n 1+n 2-2}
\end{array}
$$

\section{HASIL}

\subsection{Uji Homogenitas}

Tahap awal melakukan uji normalitas soal ulangan kesetimbangan ion dan $\mathrm{pH}$ larutan garam karena data yang akan digunakan untuk uji homogenitas dalam penelitian adalah data yang didapatkan dari nilai soal ulangan kesetimbangan ion dan $\mathrm{pH}$ larutan garam yang telah terdistribusi normal. Hasil analisis uji normalitas dapat dilihat pada Tabel 2.

Tabel 2. Hasil uji normalitas

\begin{tabular}{lccccccc}
\hline \multicolumn{1}{c}{ Data } & Kelas & $\mathbf{N}$ & $\overline{\mathrm{x}}$ & $\mathbf{S}$ & Lmaks & Ltabel & Keterangan \\
\hline Nilai ulangan & XI MIA 1 & 3 & 74,86 & 8,15 & 0,16 & 0,15 & Tidak Berdistribusi \\
Kesetimbangan & & 6 & & & & & Normal \\
ion dan pH & XI MIA 2 & 3 & 74,44 & 7,90 & 0,13 & 0,15 & Berdistribusi Normal \\
larutan garam & & 6 & & & & & \\
& XI MIA 3 & 3 & 71,25 & 9,05 & 0,14 & 0,15 & Berdistribusi Normal \\
& & 6 & & 10,7 & & & \\
& XI MIA 4 & 3 & 58 & 9 & 0,14 & 0,15 & Berdistribusi Normal \\
\hline
\end{tabular}

Dari hasil Tabel 2 terlihat hasil dari empat kelas, terdapat 3 kelas yang berdistribusi normal ialah kelas XI MIA 2, XI MIA 3, dan XI MIA 4 dimana harga $\mathrm{L}_{\text {maks }}<\mathrm{L}_{\text {tabel. }}$ Kemudian dilakukan uji kesamaan rata-rata dua pihak agar mengetahui kehomogenan dari kedua kelas tersebut. Pelaksanaan uji varians sebagai syarat dari uji homogenitas, karena data yang diuji harus mempunyai varians yang sama. Data hasil pengolahan dari uji homogenitas dapat dilihat pada Tabel 3.

Berdsarkan Tabel 3 terlihat bahwa dari masing-masing pasangan kelas yang telah diuji homogenitasnya didapat 1 pasangan kelas yang homogen yaitu kelas XI MIA 2 dengan XI MIA 3. Satu pasang kelas yang telah homogen ini dapat dikatakan sebagai pasangan kelas yang layak untuk dilakukan penelitian dengan memilih satu pasangan kelas secara acak (diundi) yang akan dijadikan kelas eksperimen dan kontrol kemudian dipilih kelas XI MIA 2 sebagai kelas eksperimen dan kelas XI MIA 3 sebagai kelas kontrol. 
Tabel 3. Hasil pengolahan data uji homogenitas

\begin{tabular}{ccccccccc}
\hline Kelas & $\mathbf{N}$ & $\sum \mathbf{X}$ & $\overline{\mathrm{x}}$ & $\mathbf{F}$ hitung & $\mathbf{F}$ tabel & thitung & t tabel & Keterangan \\
\hline $\begin{array}{c}\text { XI MIA 2 } \\
\text { dan }\end{array}$ & 36 & 2680 & 74,44 & 1,31 & 1,72 & 1,59 & 1,6 & Homogen \\
XI MIA 3 & 36 & 2565 & 71,25 & & & & 7 & \\
\hline $\begin{array}{c}\text { XI MIA 2 } \\
\text { dan }\end{array}$ & 36 & 2680 & 74,44 & 1,86 & 1,74 & 6,87 & 1,6 & Tidak Homogen \\
XI MIA 4 & 36 & 2030 & 58 & & & & 7 & \\
\hline $\begin{array}{c}\text { XI MIA 3 } \\
\text { dan }\end{array}$ & 36 & 2565 & 71,25 & 1,42 & 1,74 & 5,60 & 1,6 & Tidak Homogen \\
XI MIA 4 & 36 & 2030 & 58 & & & & 7 & \\
\hline
\end{tabular}

\subsection{Uji Hipotesis}

Selisih antara nilai pretest dan posttest yang menunjukkan besarnya peningkatan prestasi peserta didik sebelum dan sesudah mempelajari materi kesetimbangan ion dan $\mathrm{pH}$ larutan penyangga dengan dan tanpa menggunakan model pembelajaran cooperative script akan dijadikan sebagai data untuk pengujian hipotesis. Hasil pengolahan data uji hipotesis dapat dilihat pada Tabel 4.

Tabel 4. Hasil uji hipotesis

\begin{tabular}{cccccccc}
\hline Kelas & $\mathbf{N}$ & $\sum \mathbf{X}$ & $\bar{X}$ & $\mathbf{S}_{\text {gab }}$ & thitung & t tabel & keterangan \\
\hline Eksperimen & 36 & 1606 & 44,61 & \multirow{2}{*}{5,35} & \multirow{2}{*}{3,74} & \multirow{2}{*}{1,66} & \multirow{2}{*}{ Hipotesis diterima } \\
Kontrol & 36 & 1436 & 39,89 & & & & \\
\hline
\end{tabular}

Pengujian hipotesis dilaksanakan dengan menerapkan uji t pihak kanan, dimana hasil uji hipotesis thitung $=3,74$ sedangkan nilai tabel pada $\alpha=0,05$ dengan $\mathrm{dk}=70$ adalah 1,66 maka artinya thitung lebih besar dari pada tabel yaitu 3,74>1,67 sehingga hipotesis diterima, artinya adanya peningkatan prestasi belajar peserta didik dengan penerapan model pembelajaran cooperative script dapat diterima.

\section{PEMBAHASAN}

Peningkatan prestasi belajar peserta didik pada kelas eksperimen disebabkan karena menggunakan model pembelajaran Cooperative Script yang dapat membuat aktivitas peserta didik dalam proses pembelajaran tidak hanya didominasi oleh peserta didik yang sama tetapi oleh seluruh peserta didik serta mampu membuat peserta didik lebih ingat materi dan memberikan pengalaman belajar kepada peserta didik karena peserta didik lebih berperan aktif dalam proses pembelajaran sehingga pembelajaran menjadi bermakna. Menurut Slavin (2009) Cooperative Script adalah model belajar dimana peserta didik bekerja berpasangan dan bergantian peran sebagai pembicara atau pendengar dalam membahas bagian-bagian yang dipelajari. Dengan kata lain, model Cooperative Script merupakan model belajar yang membutuhkan kerja sama antara satu sebagai pembicara dan satunya sebagai pendengar.

Model pembelajaran Cooperative Script menuntut peserta didik bekerja sama secara berpasangan. Peserta didik diminta membuat ringkasan dari bahan ajar yang berupa kompilasi materi pelajaran dan secara bergantian membacakan ringkasan yang telah mereka buat. Sementara satu peserta didik membaca ringkasan, peserta didik yang lain mendengarkan dan mengoreksi kesalahankesalahan atau bagian-bagian yang kurang lengkap, kemudian melengkapi ringkasan yang dianggap kurang berdasarkan indikator yang diminta pada bahan ajar dan menyimpulkan materi bersama-sama. Dengan demikian semua peserta didik terlibat dan menjadi aktif dalam proses belajar mengajar. Jika 
peserta didik terlibat aktif dalam proses pembelajaran, maka kesan penerimaan pelajaran akan melekat lebih lama. Sebagaimana yang diutarakan oleh Jacobs (1996) bahwa pembelajaran Cooperative Script merupakan pembelajaran yang mengembangkan upaya kerja sama dalam mencapai tujuan bersama, dapat meningkatkan pemahaman dan ingatan peserta didik, serta dapat meningkatkan prestasi belajar peserta didik. Berdasarkan hasil penelitian, dapat dikatakan bahwa pembuatan ringkasan dapat berpengaruh terhadap prestasi belajar peserta didik, yang dapat dilihat dari hasil evaluasi peserta didik pada setiap pertemuan yang semakin meningkat. Jika dibandingkan dengan kelas kontrol yang tidak membuat ringkasan sebelumnya, maka hasil evaluasi peserta didik pada kelas eksperimen lebih tinggi. Keaktifan peserta didik terlihat pada kegiatan diskusi membacakan hasil ringkasan, dimana peserta didik dapat saling menghargai dan mendengarkan pendapat temannya selaku pembicara ataupun pendengar, peserta didik mau mengoreksi atau memperbaiki jika ada kesalahan atau kekurangan pada ringkasan temannya. Begitu pula yang terjadi selama penelitian berlangsung. Ketika kegiatan diskusi dilakukan, setiap pasangan dapat melakukan perannya, baik sebagai pembicara ataupun pendengar. Peserta didik yang berperan sebagai pembicara mau mendengarkan koreksi, pendapat dan masukan yang diberikan oleh pendengar. Begitu juga sebaliknya, peserta didik yang berperan sebagai pendengar mau mendengarkan temannya yang sedang membacakan ringkasan dengan baik. Hasil diskusi mereka selanjutnya mereka simpulkan bersama-sama dan dituliskan pada lembar ringkasan kelompok. Menurut Yamin (2013) meningkatnya kemampuan peserta didik dalam menyelesaikan persoalan dengan berinteraksi antar teman sebaya, dimana jika bertukar ide antar teman kelompoknya, peserta didik akan saling mudah memahami materinya.

\section{KESIMPULAN DAN REKOMENDASI}

\subsection{Kesimpulan}

Dari semua data perhitungan hingga pembahasan yang telah dilakukan, maka dapat disimpulkan dengan adanya penerapan model pembelajaran Cooperative Script akan meningkatkan prestasi belajar peserta didik pada pokok bahasan kesetimbangan ion dan $\mathrm{pH}$ larutan penyangga di kelas XI MIA SMA Negeri 9 Pekanbaru dengan menggunakan analisis uji-t pihak kanan, hasil uji hipotesis thitung $=3,74$ dan nilai tabel pada $\alpha=0,05$ dengan $\mathrm{dk}=70$ adalah 1,66 , artinya thitung lebih besar daripada tabel yaitu 3,74>1,66 sehingga $\mathrm{H}_{\text {a }}$ diterima.

\subsection{Rekomendasi}

Dari kesimpulan yang didapat, peneliti memilih akan merekomendasikan kepada guru bidang studi kimia agar dapat menerapkan model pembelajaran Cooperative Script sebagai salah satu pilihan alternatif model pembelajaran dengan tujuan meningkatkan prestasi belajar peserta didik terkhusus pada pokok bahasan kesetimbangan ion dan $\mathrm{pH}$ larutan penyangga.

\section{DAFTAR PUSTAKA}

Aris, S. 2014. 68 Model Pembelajaran Inovatif dalam Kurikulum 2013. Arruzz Media: Yogyakarta.

Heni dan Karwono. 2017. Belajar dan Pembelajaran Serta Pemanfaatan Sumber Belajar. PT Rajagrafindo Persada: Depok.

Jacobs, G. M., Lee, G. S., \& Ball, J. 1996. Learning Cooperative Learning Via Cooperative Learning. A Source book of Lesson Plans for Teacher Education on Cooperative Learning. SEAMEO Regional Language Centre. Singapore.

Kristaliningtyas, B., Utomo, S.B., Yamtinah, S. 2018. Penerapan Model Pembelajaran Cooperative Script Untuk Meningkatkan Kemampuan Memahami Bacaan dan Prestasi Belajar Pada Materi Pokok Hidrolisis Garam Kelas XI IPA 2 Semester Genap SMA Negeri 1 Ngemplak Tahun Pelajaran 2016/2017. Jurnal Pendidikan Kimia 7(1): 236-243. FKIP Universitas Sebelas Maret: Surakarta 
Norshofiati, Hamid, A., Bakti, I. 2017. Efektivitas model pembelajaran cooperative script dikombinasikan dengan model tps terhadap kemampuan kritis siswa pada materi koloid kelas xi ipa sma negeri 12 banjarmasin. Journal of Chemistry And Education. 1(1): 93-103

Nugroho, A. Nugraha, I. 2008. Berpetualang Di dunia Kimia. Pustaka Insan Madani. Yogyakarta Rostina, S. 2014. Statistika Penelitian Pendidikan. Alfabeta: Bandung.

Slavin, R. 2010. Cooperative Learning; Teori, Riset dan Praktik. Nusa Media: Bandung.

Sudjana, A. 2008. Pengantar Evaluasi Pendidikan. Gravindo Persada: Jakarta.

Yamin, M. 2013. Strategi dan Model Pembelajaran. GP Press Group: Jakarta. 